\title{
A PRIMER ON THE DIRECTORS' OVERSIGHT FUNCTION AS A STANDARD OF DIRECTORS' CONDUCT UNDER THE COMPANIES ACT 71 OF 2008
}

Jan Louis Van Tonder

LLB LLM, Postgraduate Certificate, Competition

Law Postgraduate Diploma, EU Competition Law Research Associate, Faculty of Law, Mercantile Law Department, Nelson Mandela University Attorney and Conveyancer of the High Court of South Africa

\section{SUMMARY}

The recent well publicised corporate scandals and widespread allegations of corporate fraud and corruption in both the private and public sector, which occurred seemingly unnoticed and caused public outrage, prompted this article. Although it is clear that directors should not be passive in their monitoring and oversight function and the notion of a passive director must be discouraged, as such, the oversight function has received little or no attention in South Africa, and is, as a result, not well developed in South Africa. The aim of this article is to provide a preliminary analysis of the content and meaning of the directors' oversight function as a standard of directors' conduct and to reconcile the oversight function with the business judgment rule. Section 5(2) of the Companies Act provides that, to the extent appropriate, a court interpreting or applying the provisions of the Companies Act may consider foreign company law. This is complementary to section 5(1), which directs that the Companies Act must be interpreted and applied in a manner that gives effect to the purpose of section 7. In light hereof, the article will refer to the Model Business Corporation Act to assist the research in examining the content and meaning of the oversight function as a standard of directors' conduct and to reconcile the oversight function with the business judgment rule.

\section{INTRODUCTION}

The board of directors is conferred with the statutory authority to manage the business and affairs of a company and to exercise all the powers and 
perform any of the functions of the company. ${ }^{1}$ In turn, it is recognised that the exercise of this statutory power carries with it certain fundamental fiduciary obligations to the company. ${ }^{2}$ Section 76 of the Companies Act 71 of $2008^{3}$ partially codifies ${ }^{4}$ the director's fiduciary duties, the duty of care, skill and diligence and introduces the business judgment rule ${ }^{5}$ in the standards of directors' conduct provision.

Traditionally, these duties are mainly concerned with specific decisions or actions by the board that turn out poorly and the availability of the deference mechanism of the business judgment rule to protect directors from personal liability for the resulting harm or losses. On the other hand, the oversight function $^{6}$ deals with the directors' responsibility to actively monitor company officers, employees, and corporate affairs. ${ }^{7}$ As a duty, it requires directors to monitor officers, employees and the company's policies and affairs in order to prevent any wrongdoing that can cause harm or loss to the company and that wrongdoing can be attributed to the directors' failure to discharge their oversight responsibilities. $^{8}$ For directors' liability to arise, it must be shown that the director failed to take action under circumstances where it can be proven that the director should have acted in order to prevent that loss or harm to the company. ${ }^{9}$

The recent well-publicised corporate scandals and widespread allegations of corporate fraud and corruption in both the private and public sector, which occurred seemingly unnoticed and caused public outrage, prompted this article. $^{10}$ Although it is clear that directors should not be passive in their monitoring and oversight function and the notion of a passive director must be discouraged, as such, the oversight function has received little or no

S 66(1).

S 76.

Hereinafter "the Companies Act".

Coetzee and Van Tonder "Advantages and Disadvantages of Partial Codification of Directors' Duties in the South African Companies Act 71 of 2008" 2016 41(2) Journal for Juridical Science 1-14.

S 76(4).

6 Also referred to as the directors' duty of oversight or the duty to monitor in the United States of America.

7 Fairfax "Managing Expectations: Does the Directors' Duty To Monitor Promise More Than It Can Deliver?" 2014 10(2) University of St. Thomas LJ 416.

$8 \mathrm{Ibid}$; see the Delaware case of Stone ex rel. Am-South Bancorporation v Ritter 911 A.2d 362370 (Del. 2006).

9 Fairfax 2014 10(2) University of St. Thomas LJ 416; see the Delaware cases of Stone ex rel. Am-South Bancorporation v Ritter supra 370; In re Caremark Int'I Inc. Derivative Litig. 698 A.2d 959967 (Del. Ch.1996).

10 See amongst others Kew and Bonorchis "Steinhoff Fights for Survival as South Africa Joins Probes" 7 December 2017 https://www.bloomberg.com/news/articles/2017-12-07/steinhoffshares-extend-record-plunge-after-ceo-quits-amid-probe (accessed 2017-12-07); Cohen and Gumede "KPMG and McKinsey Feel the Heat as Graft Scandal Rocks SA" 19 September 2017 https://www.fin24.com/Companies/Financial-Services/kpmg-and-mckinsey -feel-the-heat-as-graftscandal-rocks-sa-20170919 (accessed 2017-09-21); see amongst others Gedye "Construction: Firms Hit by Cartel Scam may Sue for Billions" 15 February 2013 http://www.mg.co.za/article/2013-02-15-00-firms-hit-by-cartel-scam-may sue for billions (accessed 2013-03-22). 
attention in South Africa, and is, as a result, not well developed in South Africa.

The aim of this article is to provide a preliminary analysis of the content and meaning of the directors' oversight function as a standard of directors' conduct and to reconcile the oversight function with the business judgment rule. The article is not intended to deal with the possible basis of liability for breach of the directors' oversight function. Due to the undeveloped nature of the oversight function in South Africa, the research relies on section 5(2) of the Companies Act, which provides that, to the extent appropriate, a court interpreting or applying the provisions of the Companies Act may consider foreign company law. This is complementary to section $5(1)$, which directs that the Companies Act must be interpreted and applied in a manner that gives effect to the purpose of section 7 . $^{1}$

The Model Business Corporation Act ${ }^{12}$ is widely regarded as one of the most significant and influential corporations law statutes in the United States of America. The MBCA makes a specific distinction between the directors' decision-making function and the directors' oversight function. The MBCA also specifically and distinctly deals with standards of directors' conduct and standards of directors' liability. The former addresses the level of performance expected of directors undertaking the role and responsibilities of the office of director. ${ }^{13}$ Although this provision does not address directors' liability, exposure to liability may result from a failure by directors to discharge their standards of conduct. ${ }^{14}$ In order to provide a contextual and holistic analysis of the content and meaning of the oversight function as a standard of directors' conduct the article also examines the relevant standards of directors' liability provision. The MBCA provides a model "bright-line" approach to these issues, which has indirectly been influenced by Delaware's highly developed corporate law. This will assist the research in providing a preliminary analysis of the content and meaning of the oversight function as a standard of directors' conduct. The legislative corporate framework of the MBCA as well as, the history and development of the directors' oversight function will also be discussed in order to provide context to the content and meaning of the oversight function as applied and developed in United States corporate law. The conceptual and fundamental differences between the nature and legal categorisation of South African corporate law relating to fiduciary duties and United States corporate law relating to fiduciary duties, is beyond the scope of this article. Any reference to "director or directors" in this article means a director that is a full-time or executive director and who participates in the day-to-day management of the company's affairs and business unless the context indicates otherwise.

11 In this regard the Companies Act is aimed at balancing the rights and obligations of shareholders and directors within companies (S 7(i)); and encourages the efficient and responsible management of companies (S 7(j)).

12 The Model Business Corporation Act (Revised 2016) (December 9, 2016); Reference will also be made to the Model Business Corporation Act $3^{\text {rd }}$ Edition (2005); hereinafter the "MBCA" and "MBCA 3ed (2005)" respectively.

13 MBCA official comment 180

14 Ibid. 
First, it is necessary to determine the position of the directors' oversight function under the South African corporate law in order to establish a benchmark to examine the content and meaning of the oversight function as a standard of directors' conduct under the MBCA.

\section{SOUTH AFRICAN CORPORATE LAW}

\section{The Companies Act}

It is now a matter of statutory law that the company's business and affairs must be managed by or under the direction of its board. ${ }^{15}$ Accordingly, the board has the authority to exercise all of the powers and perform any of the functions of the company. ${ }^{16}$ The statutory managerial authority enables the board to direct the management of a company, to monitor its senior officers, employees, the company's business and affairs and to make business decisions. $^{17}$ The fiduciary duties require directors when acting in that capacity, to exercise their powers and perform their functions in good faith and for a proper purpose in the best interests of the company. ${ }^{18}$ The duty of care, skill and diligence regulates the performance of these duties. ${ }^{19}$ The business judgment rule provides the circumstances in which the duty to act in the best interests of the company and the decision-making function of the duty of care, skill and diligence will be satisfied by a director. ${ }^{20}$

This indicates that the management function of directors can be divided into two broad areas, namely decision-making and oversight. ${ }^{21}$ The decisionmaking function requires the board to determine matters of policy and to make significant decisions that plan the company's future. ${ }^{22}$ It applies to all decisions directors make, or should, where they exercise their powers to the benefit of the company. ${ }^{23}$ The oversight function requires the board to monitor those assigned to carry out the board's decisions and to oversee the management of the company. ${ }^{24}$ The standard of conduct required of a

15 S 66(1)

16 Except to the extent that the Companies Act or the company's Memorandum of Incorporation provides otherwise - S 66(1).

17 Alces "Beyond the Board of Directors" 201146 Wake Forest LR 783.

18 S 76(3)(a) and (b).

19 See Cilliers, Benade, Henning, Du Plessis, Delport, De Koker and Pretorius Corporate Law 3ed (2000) 147

20 S 76(4)(a); see also Visser Sitrus (Pty) Ltd v Goede Hoop Sitrus (Pty) Ltd 2014 (5) SA 179 (WCC) par 80; Van Tonder "An Analysis of the Directors' Decision-making Function Through the Lens of the Business-judgment Rule" 2016 37(3) Obiter 562.

21 In re Caremark Int'l Inc. Derivative Litig. supra 968; see also Committee on Corporate Laws, ABA Section of Business Law "Corporate Director's Guidebook, Fifth Edition" 200762 The Business Lawyer 1494 provides that "A director's duty of care primarily relates to the responsibility to become informed in making decisions and overseeing the management of the corporation".

22 In re Caremark Int'l Inc. Derivative Litig. supra 968.

23 Bekink "An Historical Overview of the Director's Duty of Care and Skill: From the Nineteenth Century to the Companies Bill of 2007" 200820 South African Mercantile LJ 95; Havenga "The Business Judgment Rule - Should We Follow the Australian Example?" 200012 South African Mercantile LJ 25.

24 In re Caremark Int'l Inc. Derivative Litig. supra 968. 
director to discharge his decision-making function is that a director must take reasonably diligent steps to become informed about the matter. ${ }^{25}$ However, section 76 provides no standard of directors' conduct for the oversight function.

Section 76(3)(c) provides for the director's duty of care, skill and diligence. The word "diligence" is a new addition to the director's partially codified duty of care and skill. Arguably, this addition represents an extension of the common law duty of care and skill. ${ }^{26}$ According to Cassim, ${ }^{27}$ the wording of the provision suggests, "care and "skill" is different from "diligence". South African commentators or South African courts have hardly ever used the word "diligence" ${ }^{28}$ According to Black's Law Dictionary ${ }^{29}$ "diligence" means "[p]rudence; vigilant activity; attentiveness; or care, of which there are infinite shades, from the slightest momentary thought to the most vigilant anxiety". This would include attendances at the board and other meetings ${ }^{30}$ and attention to related paperwork, devoting attention to the company's affairs and the proper supervision and general monitoring of corporate affairs and policies.

Other than these discussions there is nothing else in the Companies Act (or its regulations) that gives an indication of what can be required of directors to discharge their oversight function as a standard of directors' conduct or what the content and meaning of the directors' oversight function is.

\section{Case law and best practices}

Apart from the summary provided by Margo $\mathrm{J}$ in Fisheries Development Corporation of SA Ltd $v$ Jorgensen; Fisheries Development Corporation of $S A L t d v A W J$ Investments (Pty) $L t d^{32}$ relating to the duty of care and skill, ${ }^{33}$

25 S 76(4)(a)(i).

26 Du Plessis "A Comparative Analysis of Directors' Duty of Care, Skill and Diligence in South Africa and in Australia: Corporate Governance and Mergers and Takeovers: Part II" 2010 Acta Juridica: Modern Company Law for a Competitive South African Economy 268; Cassim (man ed), Cassim, Cassim, Jooste, Shev and Yeats Contemporary Company Law 2ed (2012) 559.

27 Cassim et al Contemporary Company Law 559

28 Du Plessis 2010 Acta Juridica: Modern Company Law for a Competitive South African Economy 268.

29 Black Black's Law Dictionary 544.

30 In Charitable Corporation v Sutton (1742) 26 ER 642 644-645 Lord Hardwicke held that "(if directors) are guilty of gross non-attendance and leave the management entirely to others, they may be guilty by this means of the breaches of trust that are committed by others".

31 Cassim et al Contemporary Company Law 560; Interestingly, in terms of s 128 of the Companies Act a business rescue practitioner means a person appointed, or two or more persons appointed jointly, in terms of Chapter 6 to oversee a company during business rescue proceedings. The business rescue practitioner, by his definition, is required to supervise the company during business rescue proceedings. "Supervision" is defined in $s$ 128 to mean the oversight imposed on a company during its business rescue proceedings (own emphasis added)

32 [1980] 4 All SA 525 (W) 533-534.

33 The decisions referred to include Lagunas Nitrate Co v Lagunas Syndicate [1899] 2 Ch 392 (CA); In re Brazilian Rubber Plantations and Estates Ltd [1911] 1 Ch 425 (CA) In re City 
for the oversight function the courts in South Africa have also not yet provided direct authoritative guidance on the content and meaning of the oversight function or the standard of conduct expected of directors when discharging their oversight function.

The King IV Report on Corporate Governance for South Africa $2016^{34}$ makes provision for broader corporate governance principles and recommendations that indirectly provides general guidance on the director's oversight function. ${ }^{35}$ Although the King IV Report applies to all companies, it is not law. ${ }^{36}$ However, as Delport ${ }^{37}$ points out, it may have an effect on the possible liability of directors if it is not complied with ${ }^{38}$ In this regard, there is a divergence between aspirational standards of corporate governance best practices and legally enforceable standards of review that will actually result in direct director liability. ${ }^{39}$

In Brehm v Eisner ${ }^{40}$ it was submitted that

"[a]spirational ideals of good corporate governance practices for boards of directors that go beyond the minimal legal requirements of the corporation law are highly desirable, often tend to benefit stockholders, sometimes reduce litigation and can usually help directors avoid liability. But they are not required by the corporation law and do not define standards of liability".

The King Report IV deals with aspirational principles and standards of good corporate governance, which are highly desirable but ultimately does

Equitable Fire Insurance Co Ltd [1925] 1 Ch 407 (CA); Dovey v Cory 1901 AC 477 (HL); In re National Bank of Wales Ltd (1899) 2 Ch 629 (CA) and Huckerby $v$ Elliot [1970] 1 All ER 189.

34 The Institute of Directors in Southern Africa NPC 2016 (hereinafter "King IV Report").

35 See King IV Report "King IV Code on Corporate Governance" 42.

36 King IV Report "Application and Disclosure" 34; Delport The New Companies Act Manual 2ed (2011) 93.

37 Delport The New Companies Act Manual 93.

38 See Esser and Delport "The Duty of Care, Skill and Diligence: The King Report and the 2008 Companies Act" 201174 THRHR 449; see also De Villiers v BOE Bank Ltd 20042 All SA 457 (SCA); Minister of Water Affairs and Forestry v Stilfontein Gold Mining Co Ltd 2006 (5) SA 333 (W); South African Broadcasting Corporation Ltd v Mpofu [2009] 4 All SA 169 (GSJ).

39 See Velasco "The Role of Aspiration in Corporate Fiduciary Duties" 201254 WM and Mary LR 519; Coffee Jr. "Paradigms Lost: The Blurring of the Criminal and Civil Law Models And What Can Be Done About It" 1992101 Yale LJ 1875; Rock "Saints and Sinners: How Does Delaware Corporate Law Work?" 199744 UCLA LR 1009; Rock and Wachter "Islands of Conscious Power: Law, Norms, and the Self-Governing Corporation" 2001149 U Pa LR 1619; Hill and McDonnell "Executive Compensation and the Optimal Penumbra of Delaware Corporation Law" 20094 Va. L. and Bus. Rev. 333; Blair and Stout "Trust, Trustworthiness, and the Behavioral Foundations of Corporate Law" 2001149 U Pa LR 1735; see further on the divergence in corporate law between standards of conduct and standards of liability Eisenberg "The Divergence of Standards of Conduct and Standards of Review in Corporate Law" 199362 Fordham LR 437; Allen, Jacobs and Strine Jr. "Function Over Form: A Reassessment of Standards of Review in Delaware Corporate Law" 200156 The Business Lawyer 1287; Dan-Cohen "Decision Rules and Conduct Rules: On Acoustic Separation in Criminal Law" 199362 Fordham LR 437; Smith "A Proposal to Eliminate Director Standards from the Model Business Corporation Act” 199967 U Cin LR 12011203.

40746 A.2d 244 (Del. 2000).

41 Brehm $v$ Eisner supra 256. 
not provide for standards of directors' conduct or instances in which direct liability will be imposed for a breach of a legal duty.

\section{THE MODEL BUSINESS CORPORATION ACT}

\section{The corporate legislative framework of the MBCA}

Corporations in the United States must comply with applicable federal statutes, applicable listing rules, relevant state statutes, and common law and should be responsive to market expectations regarding their behaviour. ${ }^{42}$ The primary component in the regulatory framework for corporations is the state corporation statute of the relevant state of organisation, although the federal securities laws, as well as applicable listing rules, will apply to public corporations. ${ }^{43}$ In terms of the internal affairs doctrine, the laws of the state of incorporation govern the internal affairs of corporations incorporated therein, except where the law conflicts with national policy on foreign interstate commerce. ${ }^{44}$

The MBCA is designed as a freestanding general corporation statute that can be enacted substantially or in its entirety by a state legislature. ${ }^{45}$ More than half of the United States has adopted all or substantially all of the MBCA as their general corporation statute. ${ }^{46}$ The Committee on Corporate Laws of the American Bar Association drafted and revised the MBCA. ${ }^{47}$ Each section of the MBCA is followed by the official comment, prepared by the Committee, which amplifies and explains the purpose, rationale, and operation of the statute. ${ }^{48}$ Some states that have adopted the MBCA have also adopted the official comment, sometimes with state-specific changes. ${ }^{49}$ Statutory cross-references have also been added after each section. ${ }^{50}$ It is suggested that Delaware corporate law and the MBCA operate in symbiosis with each other, although this was not the intention of the drafters of the separate models. ${ }^{51}$ The two models influence each other on a continuous basis. ${ }^{52}$ The three main elements of this symbiosis are: $:^{53}$

(i) each model has been informed by drafting and case law experience generated under the other;

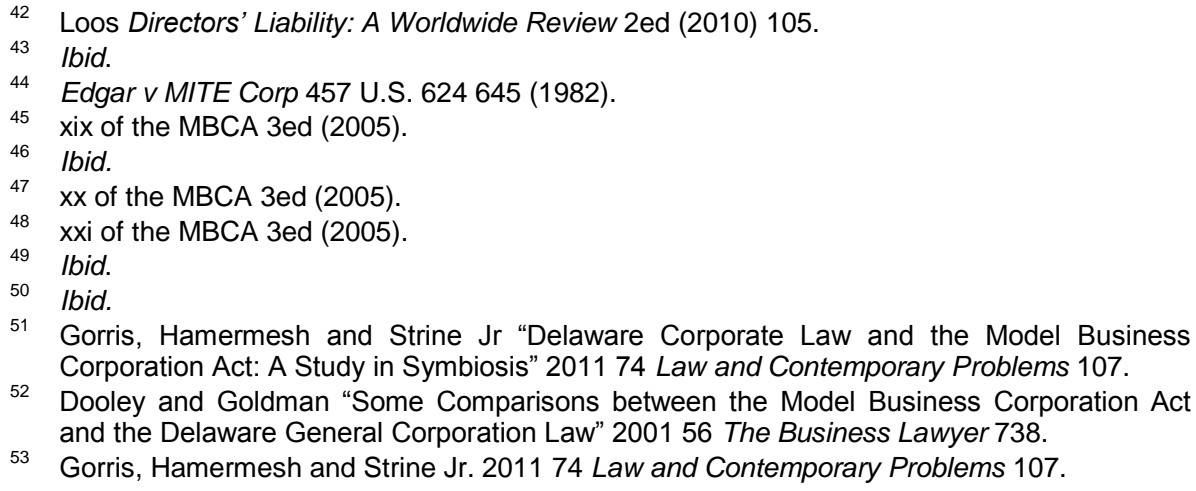


(ii) in recent years, the Delaware case law has initiated important elements of the corporate law, subsequently adopted by the MBCA; and

(iii) the deliberative style of the MBCA has led to useful refinements in Delaware law.

It is suggested that Delaware corporate law is the initiator in the symbiosis while the MBCA acts as the refiner even though they remain usefully distinct. ${ }^{54}$ Delaware's circumstance motivates it to innovate, the MBCA's institutional character allows it to restate, refine, and clarify. ${ }^{55}$ it is suggested that the constant reinforcement serves both models well, in ways their drafters never predicted. ${ }^{56}$

The most significant difference between the two sets of law is their approach in some circumstances. While the Delaware General Corporation $\mathrm{Law}^{57}$ prefers its statutory standards to be expressed in more general terms, leaving case law and lawyers to fill in the interstices, ${ }^{58}$ the MBCA adopts a "bright-line" approach. It is the foundation and substance behind this approach, which the research intends to use to provide content and meaning to the director's oversight function as a standard of directors' conduct.

\section{History and development of the directors' oversight function}

At the turn of the millennium, several corporate scandals broke out in the United States, including, amongst others, corporations such as Enron, WorldCom, Qwest, Global Crossing, and Tyco International, which collectively cost shareholders $\$ 460$ billion. ${ }^{59}$ Generally, these scandals involved fraudulent accounting transactions designed by corrupt managers to make financial statements appear healthier than what they really were. ${ }^{60}$ These corporate failures focused more attention on the corporate governance of directors' duties. ${ }^{61}$ Veasey, a prominent Delaware jurist at the time and closely associated with the principle of deference, ${ }^{62}$ submitted that "the main corporate governance failure (has been) the lassitude and indifference of some boards of directors who were not proactive in their

54 Gorris, Hamermesh and Strine Jr. 201174 Law and Contemporary Problems 112-120.

55 Gorris, Hamermesh and Strine Jr. 201174 Law and Contemporary Problems 120.

56 lbid.

57 Title 8 Chapter 1 of the Delaware Code.

58 Dooley and Goldman 200156 The Business Lawyer 764-765.

59 Bainbridge, Lopez and Oklan "The Convergence of Good Faith and Oversight" 200855 UCLA LR 571.

60 Ribstein "Market vs. Regulatory Responses to Corporate Fraud: A Critique of the SarbanesOxley Act of 2002" 200228 J CORP L 1 4; Bainbridge, Lopez and Oklan 200855 UCLA LR 573.

61 Cunningham "The Sarbanes-Oxley Yawn: Heavy Rhetoric, Light Reform (And It Might Just Work)" 200335 Connecticut LR 917; Langevoort "Internal Controls After Sarbanes-Oxley: Revisiting Corporate Law's Duty of Care as Responsibility for Systems" 200631 Journal of Corporation Law 949; Olson and Briggs "The Model Business Corporation Act and Corporate Governance: An Enabling Statute Moves Towards Normative Standards" 2011 74 Law and Contemporary Problems 31-32.

62 Bainbridge, Lopez and Oklan 200855 UCLA LR 572 
oversight and strategic roles". ${ }^{63}$ Bainbridge ${ }^{64}$ explains, "[t]he public outrage triggered by the corporate scandals prompted a number of regulatory responses intended to prevent a recurrence of such 'lassitude and indifference'".

At the federal level, the Sarbanes-Oxley Act ${ }^{65}$ expanded disclosure and governance rules. $^{66}$ In addition, the New York Stock Exchange and NASDAQ imposed more stringent listing standards on corporations. ${ }^{67}$

The unprecedented federal intervention into corporate governance embodied by the SOX $\mathrm{Act}^{68}$ put pressure on the Delaware judiciary to consider evolving expectations for directors and firmer legal duties. ${ }^{69}$ This led to a more aggressive approach by the Delaware courts considered to be traditionally management prone. Subsequently, in a 12-month period from mid-2002 to mid-2003 the Delaware courts produced six cases ${ }^{70}$ in which the Delaware Supreme Court held for shareholders and against directors, in some instances reversing the Court of Chancery's decisions, at least in part, and in other instances stated significant new law that did not favour protection of directors. ${ }^{71}$ Although this shift in balance was short-lived, the long-term effect of the pre-Enron and post-Enron era in respect of directors' duties and liability, as well as the role of the board, is evident and wellillustrated in the MBCA.

63 Veasey "Policy and Legal Overview of Best Corporate Governance Principles" 200356 SMU LR 2136.

64 Bainbridge, Lopez and Oklan 200855 UCLA LR 572.

65 Law 107-204 116 STAT. 745 enacted July 30 2002; hereinafter the "SOX" Act.

66 Bainbridge, Lopez and Oklan 200855 UCLA LR 572. Among other things, the SOX Act requires publicly traded companies to establish independent audit committees. The SOX Act also eliminated auditors' conflicts of interest by prohibiting auditors from performing many non-audit business services for their audit clients - Bainbridge, Lopez and Oklan 200855 UCLA LR 573; Ribstein 200228 J CORP L 1.

67 Bainbridge, Lopez and Oklan 200855 UCLA LR 572. For eg, listed companies on the New York Stock Exchange must now have a majority of independent directors - NYSE Corporate Governance Standards §303A.01 (2003); an independent audit committee NYSE Corporate Governance Standards §303A.06 (2003); and shareholder approval of equity compensation plans - NYSE Corporate Governance Standards \$303A.08 (2003). These listing standards are intended to enhance corporate accountability by increasing director oversight - Bainbridge, Lopez and Oklan 200855 UCLA LR 572.

68 It is suggested that the SOX Act does not reform corporate governance, but rather implements best practices, many of which were already being followed - Cunningham 2003 35 Connecticut LR 917; Langevoort 200631 Journal of Corporation Law 949.

69 See Bainbridge, Lopez and Oklan 200855 UCLA LR 574; Strine Jr. "Derivative Impact? Some Early Reflections on the Corporation Law Implications of the Enron Debacle" 200257 The Business Lawyer 1382 stating that "[i]n the wake of Enron, the judiciary will come under increasing pressure from stockholder-plaintiffs to approach these questions in a more coldeyed manner".

70 See Krasner v Moffett 826 A.2d 277 (Del. 2003); Omnicare Inc v NCS Healthcare Inc 818 A.2d 914 (Del. 2003); MM Cos v Liquid Audio Inc 813 A.2d 1118 (Del. 2003); Levco Alt Fund Ltd v Reader's Digest Ass'n 803 A.2d 428 (Del. 2002); Telxon Corp v Meyerson 802 A.2d 257 (Del. 2002); Saito v McKesson HBOC Inc 806 A.2d 113 (Del. 2002); Vaaler "2.02(b)(4) or not 2.02(b)(4): That is the Question" 201174 Law and Contemporary Problems 86.

71 Vaaler 201174 Law and Contemporary Problems 86. 
With regards to the role of the board, amendments to the MBCA in 1974 were indicative of the Committee's focus during the pre-Enron age on protecting directors from unreasonable expectations and resultant inappropriate liabilities. ${ }^{72}$ In a post-Enron age, the Committee again revisited the role of the board in $2005 .{ }^{73}$ During these amendments, the focus moved from director protection from liability to including oversight duties. ${ }^{74}$ Contrasting the 1974 amendments and in a direct response to the postEnron age, for the first time in the MBCA's history, set out specific director oversight responsibilities. ${ }^{75}$ The MBCA also expressly and distinctly deals with the director's decision-making function and oversight function. ${ }^{76}$

In respect of directors' liability, the evolution of governance approaches in the MBCA is also evident when the pre-Enron age is compared with the post-Enron age amendments. ${ }^{77}$ In this regard section 8.30 of the MBCA deals with the standards of directors' conduct while section 8.31 of the MBCA deals with the standards of directors' liability. The former is intended to serve only as a guide for director conduct and as points of reference for assessing a director's conduct. ${ }^{78}$ In the context of the oversight function, it is also relevant when required to assess a director's timely attention to the appropriate inquiry when particular facts and circumstances of significant concern materialise. ${ }^{79}$ A breach of these standards does not carry direct liability consequences. ${ }^{80}$ Section 8.31 lists the grounds for imposing direct liability on directors.

\section{The oversight function as a standard of directors' conduct}

Section 8.01(b) of the MBCA provides that "all corporate powers shall be exercised by or under the authority of the board of directors of the corporation, and the business and affairs of the corporation shall be managed by or under the direction, and subject to the oversight, of its board of directors ...." 1

According to the official commentary of the MBCA, generally, the board's oversight responsibilities should, in the case of a public company, at least include oversight of: business performance, plans and strategy, management's assessment of major risks to which the company is or may

\footnotetext{
Olson and Briggs 201174 Law and Contemporary Problems 33.

Ibid.

Ibid.

Olson and Briggs 201174 Law and Contemporary Problems 33; see also Committee on Corporate Laws, ABA Section of Business Law 2007 1482; Committee on Corporate Laws, ABA Section of Business Law "Corporate Director's Guidebook, Fourth Edition" 200459 The Business Lawyer 1063-1064; S 8.01(c) of the MBCA 3ed (2005).

76 See $s 8.30$ and 8.31 of the MBCA.

77 Olson and Briggs 201174 Law and Contemporary Problems 33.

78 Dooley "Rules, Standards, and the Model Business Corporations Act" 201174 Law and Contemporary Problems 49.

79 MBCA official comment 180.

80 Dooley 201174 Law and Contemporary Problems 49.

81 Own emphasis added.
} 
be exposed, the performance and compensation of executive officers, policies and practices to foster the company's compliance with law and ethical, conduct, management's preparation of the company's financial statements, management's design and assessment of effectiveness of the company's internal controls, plans for the succession of the chief executive officer and other executive officers, the composition of the board and of board committees and whether the corporation has information and reporting systems in place to provide directors with appropriate information in a timely manner. ${ }^{82}$

The official comment of the MBCA acknowledges that the scope of the oversight function will vary depending on the nature of the company's business. ${ }^{83}$ Although the different matters listed above should at least apply to all public companies, for other companies it will include some or all of those matters. ${ }^{84}$

According to section 8.30(b) of the MBCA "[t]he members of the board of directors or a board committee, when ... devoting attention to their oversight function, shall ...."

The MBCA states that:

"[t]he phrase ["]devoting attention,["] in the context of the oversight function, refers to considering such matters as the corporation's information and reporting systems generally and not to an independent investigation into particular system inadequacies or noncompliance. Although directors typically give attention to future plans and trends as well as current activities, they should not be expected to anticipate any particular problems, which the corporation may face, except in those circumstances where something has occurred to make it obvious to the board that the corporation should be addressing a particular problem.

This "involves gaining assurances from management and advisers that appropriate systems have been established, such as those concerned with legal compliance, risk assessment or internal controls". 87 These assurances should also "cover establishment of (on-going) monitoring of the systems in place, with the appropriate follow-up response when alerted to the issues requiring attention".

The standard of conduct required of directors to discharge their oversight function under section 8.01 of the MBCA, mainly involves a duty of attention. ${ }^{89}$ The official comment of the MBCA acknowledges that while the decision-making function generally involves "informed action" at a certain "point in time", the oversight function is concerned with a "continuum" and

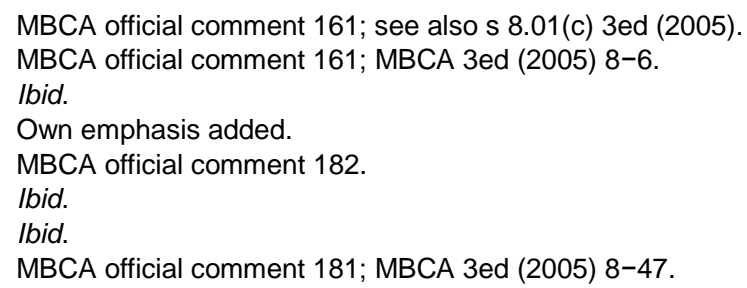


the duty of attention accordingly involves "participatory performance over a period of time". .0

\section{The oversight function as a standard of directors' liability}

The MBCA's official comment states that a director's role involves "two fundamental components: the decision-making function and the oversight function". ${ }^{91}$ The MBCA categorises the standard of liability associated with the oversight function under the title "failure to devote attention".

In order to hold a director liable for breach of his oversight function his conduct may be challenged on the basis that it involved a sustained failure to devote attention to the on-going oversight of the business and affairs of the corporation, or a failure to devote timely attention, by making (or causing to be made) appropriate inquiry, when particular facts and circumstances of significant concern materialise that would alert a reasonably attentive director to the need for such inquiry.

The oversight function under section 8.01(b) involves on-going monitoring of the company's business and affairs over a period of time. ${ }^{94}$ This involves a duty of on-going attention when actual knowledge of particular facts and circumstances raises suspicions that indicate a need to make an inquiry. ${ }^{95}$

In Francis $v$ United Jersey Bank, ${ }^{96}$ the primary issue before the Supreme Court of New Jersey was whether a director was personally liable (in negligence) for failing to prevent the misappropriation of trust funds by other directors who were also officers and shareholders of the company. The court submitted that:

"[d]irectors are under a continuing obligation to keep informed about the activities of the corporation... Directors may not shut their eyes to corporate misconduct and then claim that because they did not see the misconduct, they did not have a duty to look. The sentinel asleep at his post contributes nothing to the enterprise he is charged to protect... Directorial management does not

90 MBCA official comment 181; MBCA 3ed (2005) 8-48.

91 MBCA official comment 191; MBCA 3ed (2005) 8-71.

92 MBCA official comment 191; Under the MBCA 3ed (2005) 8-71 the standard of liability relating to the oversight function was categorised under the title "sustained inattention". In the latter instance the Caremark decision was the MBCA's influence for the adoption of the same adjective used to describe the standard of liability employed to determine director oversight liability - Committee on Corporate Laws, ABA Section of Business Law "Changes in the Model Business Corporation Act-Amendments Pertaining to Electronic Filings/Standards of Conduct and Standards of Liability for Directors" 199753 The Business Lawyer 172; Committee on Corporate Laws, ABA Section of Business Law "Changes in the Model Business Corporation Act Pertaining to the Standards of Conduct and Standards of Liability for Directors-Final Adoption" 199853 The Business Lawyer 813 (adopting s 8.31, particularly subsection (a)(2)(iv)); Gorris, Hamermesh and Strine Jr. 201174 Law and Contemporary Problems 114-115.

S 8.31(a)(2)(iv) of the MBCA

94 MBCA official comment 191; MBCA 3ed (2005) 8-71.

MBCA 3ed (2005) 8-71.

432 A.2d 814 (Sup. Ct. 1981). 
require a detailed inspection of day-to-day activities, but rather a general monitoring of corporate affairs and policies".

This means that while the facts will ultimately be "outcome-determinative", "deficient conduct involving a sustained failure to exercise oversight", where found actionable, has been characterised by the courts in the United States in terms of "abdication and continued neglect" of a director's duty of attention, not a "brief distraction or temporary interruption". ${ }^{98}$ The oversight function also requires a director to inquire when suspicions are raised or if there is a reasonable cause to be suspicious. ${ }^{99}$ This duty or need (to inquire) is not a component of the on-going oversight function and does not entail "proactive vigilance". ${ }^{100}$ It arises when, and only when, particular facts and circumstances of "material concern" surfaces. ${ }^{10}$

\section{RECONCILING THE BUSINESS JUDGMENT RULE AND THE OVERSIGHT FUNCTION}

The business judgment rule relates to the decision-making function of the duty of care, skill and diligence and presumes that directors, in making a business decision, have taken reasonably diligent steps to become informed about the matter and that the decision was made in the best interests of the company. ${ }^{102}$ Viewed through section 76(4)(a)(i), the business judgment rule, therefore, sets out the decision-making function of the duty of care, skill and diligence as a standard of directors' conduct.

The business judgment rule does not apply in matters where directors fail to adequately carry out their monitoring and oversight function. ${ }^{103}$ The business judgment rule only applies where directors have followed a due process in order to exercise a business judgment, ${ }^{104}$ while in most oversight matters directors failed to act. ${ }^{105}$ The presumption of the business judgment rule does not apply where the directors abdicate their responsibility to oversee the affairs and business of a company or where they fail to act absent a conscious decision not to act. ${ }^{106}$ Conversely, where directors are alerted of possible wrongdoing and consciously decide not to act or fail to act, their decision does in fact amount to a business decision. ${ }^{107}$ In this

\footnotetext{
Francis v United Jersey Bank supra 832.

MBCA official comment 191; MBCA 3ed (2005) 8-72.

Ibid.

Ibid.

Ibid; for eg, evidence of embezzlement at the upper level.

S 76(4)(a)(i) and (iii). Author's own emphasis.

Aronson v Lewis 473 A.2d 805813 (Del. 1984).

104 Aronson v Lewis supra 813; In re Walt Disney Co. Deriv. Litig. 907 A.2d 693748 (Del. Ch. 2005) the court held that "in instances where directors have not exercised business judgment, that is, in the event of director inaction, the protections of the business judgment rule do not apply".

105 Davis Jr. "Once More, The Business Judgment Rule" 2000 Wis LR 576 notes that in matters in which "directors are charged with negligence in failing to detect or respond to a problem" are "often referred to as the directors' 'oversight function'".

106 Aronson v Lewis supra 813.

107 Ibid.
} 
manner, the oversight function may create an incentive for directors to act or respond to reasonable suspicion of wrongdoing in order to gain the benefit of the business judgment rule.

\section{CONCLUSION}

The recent well-publicised corporate scandals and widespread allegations of corporate fraud and corruption in both the private and public sector, which occurred seemingly unnoticed and caused public outrage, prompted this article. At the turn of the millennium, the United States was faced with a spate of high profile corporate scandals, which caused similar public outrage. This prompted a number of regulatory responses, both at a federal and state level as well as the Delaware judiciary. The directors' oversight function was seen by all as a mechanism to address the recurrence of directors who were not proactive in their oversight and strategic roles. The history and development of the directors' oversight function and responsibilities are captured by the MBCA in a model bright-line approach, which illustrates this change. The aim of this article was to use this context and foundation to conduct an analysis of the content and meaning of the directors' oversight function as a standard of directors' conduct.

The South African corporate law offers little on the oversight function as a standard of directors' conduct. Generally, the broader concepts of corporate governance provide for principles and recommendations that seem to indicate that directors should actively supervise, monitor and oversee the management of the company but it is not law and does not provide guidance on the standard of conduct expected of directors in discharging their oversight function. Although the statutory managerial authority that is conferred on the board of directors in terms of section 66(1) inherently consists of a duty to monitor the business and affairs of the company, there is no express mention of the directors' oversight function under the Companies Act. Section 76(3)(c) does, however, incorporate an additional standard of diligence, which, according to the definition of the word should, in principle, require of a director to diligently keep informed about the company's activities, its officers and employees and to monitor, generally, the company's affairs and policies. However, does this provide sufficient content and meaning to the directors' oversight function in order to establish a standard of conduct that can be expected of a director?

Under the MBCA, the authority of the board of directors to manage the business and affairs of the company and to exercise all the powers and functions of the company is subject to their oversight function. The MBCA also specifically and expressly acknowledges that the role of directors consists of two fundamental components, namely the decision-making function and the oversight function.

The phrase chosen to define the standard of directors' conduct in the discharge of their oversight function is "devoting attention". The oversight function under the MBCA consists of a duty of on-going attention in relation to the corporate affairs of the company. If a director has actual knowledge of material facts that raise suspicion or is aware of an impending violation, the 
director will be required to further query and investigate the matter. Should the director fail to investigate the matter, his conduct may be challenged on the basis that it involved a sustained failure to devote attention to the ongoing oversight of the business and affairs of the company or a failure to devote timely attention by making (or causing to be made) appropriate inquiry in the face of material facts and circumstances of significant concern that would have alerted a reasonably attentive director to the need to inquire.

The primary difference between the decision-making function in the context of the business judgment rule and oversight function is that the former relates to conduct involving due process. The decision-making function is concerned with conduct that constitutes a board decision, which results in harm or loss because the director did not take reasonably diligent steps to become informed about the matter. The oversight function is concerned with conduct that constitutes an unconsidered and sustained failure by the board to act in circumstances in which due attention could have prevented the harm or loss.

In summary, the directors' oversight function relates to an obligation to prevent loss or harm to the company. The directors' oversight function as a standard of directors' conduct should require of directors, especially in public companies and listed companies, to implement a monitoring or compliance programme when required to oversee the programme's operation and periodically reassess its effectiveness and to further investigate or inquire about possible violations once the directors are alerted to possible suspicious matters or the need arises. Loss or harm to the company resulting from an alleged failure of the directors' oversight function will result in directors' liability when there was a sustained failure by the directors to devote attention to their oversight function or when there was a need to inquire and the directors failed to take appropriate action.

Should the South African legislature or courts give express recognition to the directors' oversight function and their duty to actively monitor senior officers, employees and corporate affairs, in order to prevent harm or loss to the company on whose board they serve, it will enhance their oversight function and responsibilities as a standard of directors' conduct and in so doing improve corporate governance and reduce instances of corporate wrongdoing. 